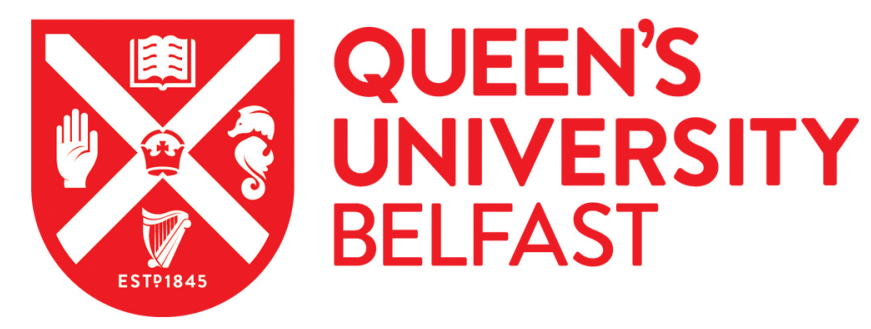

\title{
Control of Fusarium wilt of cucumber seedlings by inoculation with an arbuscular mycorrhizal fungus
}

Hao, Z. P., Christie, P., Qin, L., Wamg, C. X., \& Li, X. L. (2005). Control of Fusarium wilt of cucumber seedlings by inoculation with an arbuscular mycorrhizal fungus. Journal of Plant Nutrition, 28(11), 1961-1974. https://doi.org/10.1080/01904160500310997

Published in:

Journal of Plant Nutrition

Queen's University Belfast - Research Portal:

Link to publication record in Queen's University Belfast Research Portal

\section{General rights}

Copyright for the publications made accessible via the Queen's University Belfast Research Portal is retained by the author(s) and / or other copyright owners and it is a condition of accessing these publications that users recognise and abide by the legal requirements associated with these rights.

Take down policy

The Research Portal is Queen's institutional repository that provides access to Queen's research output. Every effort has been made to ensure that content in the Research Portal does not infringe any person's rights, or applicable UK laws. If you discover content in the Research Portal that you believe breaches copyright or violates any law, please contact openaccess@qub.ac.uk. 


\title{
Control of Fusarium Wilt of Cucumber Seedlings by Inoculation with an Arbuscular Mycorrhical Fungus
}

\section{Zhipeng Hao, ${ }^{1}$ Peter Christie, ${ }^{1,3}$ Ling Qin, ${ }^{2}$ Changxian Wang, ${ }^{1}$ and Xiaolin $\mathrm{Li}^{1}$}

\author{
${ }^{1}$ Key Laboratory of Plant Nutrition, Ministry of Agriculture; Key Laboratory of \\ Plant-Soil Interactions, Ministry of Education; and Department of Plant Nutrition, \\ College of Agricultural Resources and Environmental Sciences, China Agricultural \\ University, Beijing, China \\ ${ }^{2}$ Department of Plant Science and Technology, Beijing College of Agriculture, \\ Beijing, China \\ ${ }^{3}$ Agricultural and Environmental Science Department, Queen's University Belfast, \\ United Kingdom
}

\begin{abstract}
A glasshouse pot experiment was conducted to investigate the impact of inoculation of cucumber at the germination stage with Glomus etunicatum BEG168 on plant yield and incidence of Fusarium oxysporum f.sp. cucumerinum inoculated 28 days after the start of the experiment. Inoculation with the AM fungus decreased both disease incidence and disease index. Mycorrhizal inoculation also increased $\mathrm{P}$ concentrations in the cucumber seedlings. The mycorrhizal seedlings had higher concentrations of proline and polyphenol oxidase activity but lower malondialdehyde than non-mycorrhizal seedlings, indicating that AM inoculation may have protected membrane permeability and reduced the extent of the damage caused by $F$. oxysporum. The results indicate that the mycorrhizal fungus may influence plant secondary metabolites and increase resistance to wilt disease in cucumber seedlings and may therefore have some potential as a biological control agent.
\end{abstract}

Keywords: arbuscular mycorrhizal fungi, cucumber, wilt disease

Received 8 October 2004; accepted 20 July 2005.

Address correspondence to Xiaolin Li, Department of Plant Nutrition, College of Resources and Environment, China Agricultural University, Beijing 10094, P. R. China. E-mail: lixl@cau.edu.cn 


\section{INTRODUCTION}

Fusarium oxysporum f. sp. cucumerinum is an important soil-borne plant pathogen affecting cucumber plants (Cucumis sativus L.). Infected plantlets may develop root rot or stem canker, often leading to wilting and to plant death in severe cases (Rose et al., 2003). Fusarium wilt disease of cucumber is a worldwide problem. It is widespread in North China and is especially serious in glasshouse cropping systems (Huang et al., 1994).

Plant pathogen-root interactions and the biochemical activities that occur during root infection have been studied in some detail. There are numerous reports on the disease mechanisms and the most important factor seems to be disruption of the transport of water and nutrients in host plant vessels by the mycelium of $F$. oxysporum (de Boer et al., 2003). The resulting stress involves many physiological and biochemical changes (Magnoli et al., 1999), for example changes in enzyme activities and damage to membrane permeability.

Current cucumber disease management is based mainly on cultural practices and the use of fungicides, although chemical control is not always efficient or economically feasible for control of the disease. Biological control of the pathogen using mutualistic micro-organisms has been suggested as a potential alternative to chemical control (Park et al., 1988).

Arbuscular mycorrhizal (AM) fungi colonize species belonging to over $80 \%$ of all plant genera (Bonfante-Fasolo, 1987) and are considered to be the most widespread symbionts in plants. Arbuscular mycorrhizas are known to enhance plant uptake of phosphate $(\mathrm{P})$ and other mineral nutrients under certain conditions (Abbott and Robson, 1984). Recently, there have been reports that arbuscular mycorrhiza can induce resistance or increased tolerance to some root pathogens (Cordier et al., 1996; Trotta et al., 1996; Lingua et al., 2002), and the use of AM fungi as potential biological control agents of soilborne plant pathogens has been suggested. However, studies have indicated that sometimes arbuscular mycorrhiza can have harmful effects depending on the pathogens involved and other factors (Druge and Schonbeck, 1992; Shaul et al., 1999).

In the present investigation, a pot experiment was conducted to study the effects of inoculation with the AM fungus Glomus etunicatum BEG 168 on Fusarium wilt disease of cucumber seedlings under glasshouse conditions. In accordance with commercial horticultural practice, cucumber was inoculated with the AM fungus at germination and then supplied with a zoospore suspension of $F$. oxysporum 28 days later to determine any potential biological control effects of the AM fungus and changes in several secondary metabolites related to water stress and membrane permeability. 


\section{MATERIALS AND METHODS}

Seeds of cucumber (Cucumis sativus L. cv. Jinlv 3) obtained from the Cucumber Research Institute, Tianjin, China, were used in experiment. The seeds were surface sterilized in $10 \% \mathrm{w} / \mathrm{w}_{2} \mathrm{O}_{2}$ for $10 \mathrm{~min}$, washed thoroughly in sterile distilled water, and then pre-germinated for two days on moist filter paper at $28^{\circ} \mathrm{C}$ in the dark. Seedlings were selected for uniformity of size prior to planting.

The plant growth medium consisted of a $2: 1 \mathrm{w} / \mathrm{w}$ mixture of peat and vermiculite with the following properties: $\mathrm{pH}$ (soil:water ratio 1:2.5) 7.2, organic matter $27.1 \mathrm{~g} \mathrm{~kg}^{-1}$, Olsen-P $67.2 \mathrm{mg} \mathrm{kg}^{-1}$, NaOH-extractable $\mathrm{N} 23.3 \mathrm{mg} \mathrm{kg}^{-1}$ and $\mathrm{NH}_{4} \mathrm{Ac}$-exchangeable $\mathrm{K} 103.1 \mathrm{mg} \mathrm{kg}^{-1}$. The medium was steam-sterilized at $121^{\circ} \mathrm{C}$ for $30 \mathrm{~min}$ and air-dried. The plants were grown in 0.8 -L plastic pots sterilized with $70 \% \mathrm{v} / \mathrm{v}$ ethanol.

The AM fungus Glomus etunicatum BEG168 was propagated in pot culture on maize (Zea mays L. cv. ND108) plants in a sandy soil for 10 weeks. Inoculum from the pot culture was a mixture of spores, mycelium, sandy soil and maize root fragments. Inoculum (15 g) was mixed with the rooting medium (185 g) to produce mycorrhizal treatments, and $15 \mathrm{~g}$ sterilized inoculum plus $10 \mathrm{~mL}$ mycorrhizal fungal-free filtrate from the inoculum suspension were added to produce the non-mycorrhizal treatments in order to provide a similar microflora except for the absence of the mycorrhizal fungus.

Fusarium oxysporum f.sp. cucumerinum was grown on Potato Dextrose Agar. Synthetic medium for $F$. oxysporum consisted of liquid PDA without agar. Two pieces of 5-day-old $F$. oxysporum cultured on PDA were used as the inoculum for a $100 \mathrm{~mL}$ flask containing $50 \mathrm{~mL}$ of synthetic medium. The flask was shaken at $50 \mathrm{rpm}$ at $25^{\circ} \mathrm{C}$ to allow spore germination. Fourteen days later the mycelial inoculum was separated from the growth medium by centrifugation at $9000 \mathrm{rpm}$ and $4^{\circ} \mathrm{C}$, and then washed three times in $100 \mathrm{~mL}$ of sterile $10 \mathrm{mmol}$ $\mathrm{L}^{-1} \mathrm{MgSO}_{4} \cdot 7 \mathrm{H}_{2} \mathrm{O}$ solution.

After growth of the seedlings for 24 days, $5 \mathrm{~mL}$ of the mycelial inoculum was added aseptically to the pots at a final concentration of $10^{6}$ germinated spores $\mathrm{mL}^{-1}$ (as counted with a haemocytometer). Control plants were treated with sterile distilled water instead of the Fusarium spore suspension.

The experiment was conducted from April to July 2004 under glasshouse conditions. Deionized water was used daily to adjust the pots to field capacity. All treatments received application of $50 \%$ Hoagland nutrient solution at a rate of $40 \mathrm{~mL}$ per week.

The experiment consisted of two factors, a mycorrhizal treatment (nonmycorrhizal and inoculated with the AM fungus) and a pathogen treatment (control and inoculation with $F$. oxysporum) to give four treatments: control (no AM fungus and no F. oxysporum), inoculation with Glomus etunicatum only, inoculation with Fusarium oxysporum only, and inoculation with both Glomus etunicatum and Fusarium oxysporum. The plant pots were arranged in 
a completely randomized design with 16 replicates of each treatment, giving a total of 64 pots.

\section{Harvest and Chemical Analysis}

Final observations on disease development were made 14 days after inoculation as described by Vakalounakis et al. (2004) Eight replicate pots of each treatment were used. Tests were repeated once. Disease severity was assessed using a visual scale of 0 to 3 , where $0=$ no symptoms, $1=$ light or moderate wilt with light vascular discoloration in the stem, $2=$ severe wilt with vascular discoloration in the stem, and $3=$ dead seedlings.

Six repeats of each treatment were harvested before and 14 days after inoculation with $F$. oxysporum. Samples were carefully washed with tap water and then deionized water. Three were oven dried at $70^{\circ} \mathrm{C}$ for 48 hours to determine the biomass and $\mathrm{P}$ concentration. The others were kept at $-80^{\circ} \mathrm{C}$ prior to further processing of determination of proline and malondialdehyde (MDA) contents and polyphenol oxidase activity. Subsamples of fresh roots were collected for determination of the proportion of root length colonized by the AM fungus.

Mycorrhizal colonization was estimated using the root fragment method of Brundrett et al. (1996). Root samples were cut into 1-cm-long segments, cleared in $10 \%(\mathrm{w} / \mathrm{v}) \mathrm{KOH}$ at $90^{\circ} \mathrm{C}$ for $12-15 \mathrm{~min}$ in a water bath, acidified in $2 \%(\mathrm{v} / \mathrm{v}) \mathrm{HCl}$ and then stained with Trypan blue at $90^{\circ} \mathrm{C}$ for $15 \mathrm{~min}$. Thirty root segments from each sub-sample were observed under the microscope for colonization.

Plant samples were digested using $\mathrm{H}_{2} \mathrm{SO}_{4}-\mathrm{H}_{2} \mathrm{O}_{2}$, and phosphorus (P) was analyzed using a Model FIA-2400 flow injection analyzer.

Lipid peroxidation was estimated by measuring the formation of MDA with TBA (2-thiobarbituric acid) according to de Vos et al. (1989). Samples were harvested and transferred to $4 \mathrm{ml}$ of $0.25 \%(\mathrm{w} / \mathrm{v}) \mathrm{TBA}$ in $10 \%(\mathrm{w} / \mathrm{v})$ trichloroacetic acid (TCA) and heated at $95^{\circ} \mathrm{C}$ for $30 \mathrm{~min}$. After cooling in ice, the mixture was centrifuged at 5,000 rpm for $10 \mathrm{~min}$. MDA was determined by subtracting the absorbance of the supernatant at $600 \mathrm{~nm}$ from that at $532 \mathrm{~nm}$ (Kwon et al., 1965).

Proline content was estimated by the method of Bates et al. (1973) with slight modification. Samples (1 $\mathrm{g}$ fresh weight) were each extracted with $5 \mathrm{~mL}$ of $5 \%(\mathrm{w} / \mathrm{v})$ sulfosalicylic acid at $100^{\circ} \mathrm{C}$ for $10 \mathrm{~min}$. After cooling, the sample solution was filtered. Following this, $2 \mathrm{~mL}$ of the resulting supernatant, $2 \mathrm{~mL}$ of acid ninhydrin reagent $(1.25 \mathrm{~g}$ ninhydrin $+30 \mathrm{~mL}$ glacial acetic acid +8 $\mathrm{mL}$ orthophosphoric acid $+12 \mathrm{~mL} \mathrm{dH}_{2} \mathrm{O}$ ) and $2 \mathrm{~mL}$ of glacial acetic acid were added, and the mixture was boiled for $1 \mathrm{~h}$ in a water bath. The reaction was terminated by dipping the test tubes in an ice bath. Toluene $(4 \mathrm{~mL})$ was then added and the reaction mixture vigorously mixed on a Cyclomixer for $30 \mathrm{~s}$. The resultant chromophore extracted into the toluene phase was then aspirated 
from the aqueous phase and its absorbance was read at $520 \mathrm{~nm}$. A standard plot was also calibrated by using L-proline.

Polyphenol oxidase activity was determined by the method of Lobo and Cano (1998). Lyophilized homogenized samples $(0.5 \mathrm{~g})$ were mixed in a mortar and pestle with $0.2 \mathrm{~mol} \mathrm{~L}^{-1}$ sodium phosphate buffer ( $\mathrm{pH} 6.5,25 \mathrm{~mL}$ ). Homogenates were centrifuged in a Himac model RC-21F refrigerated superspeed centrifuge for $15 \mathrm{~min}$ at $10000 \mathrm{rpm}$ and $4^{\circ} \mathrm{C}$ until assayed for polyphenol oxidase (PPO). PPO activity was determined at $25^{\circ} \mathrm{C}$ by measuring the initial rate of increase in absorbance at $420 \mathrm{~nm}$. Unless otherwise specified, the assays of activity were carried out on $3 \mathrm{~mL}$ of reaction mixture, consisting of $0.05 \mathrm{~mol}$ $\mathrm{L}^{-1}$ catechol in $0.05 \mathrm{~mol} \mathrm{~L}^{-1}$ sodium phosphate buffer $(2.75 \mathrm{~mL}, \mathrm{pH} 6.5)$, and on aliquots of enzyme extract $(0.25 \mathrm{~mL})$. The enzyme activity unit was defined as the change in absorbance per minute per milligram of protein.

Statistical analysis of the data was carried out using the SPSS 11.0 package. Significant differences between means were established by calculation of LSD at the $5 \%$ level.

\section{RESULTS}

\section{Mycorrhizal Colonization}

No mycorrhizal colonization was observed in the roots of plants that were not inoculated with the AM fungus (Table 1). Both during the period before the plants were inoculated with $F$. oxysporum (28 days after seed germination) and 14 days after inoculation with $F$. oxysporum (42 days after seed germination), the inoculated plants had over $35 \%$ of their root length colonized. Thus, G. etunicatum produced substantial root colonization before the plants were

Table 1

Proportion of cucumber root length colonized by the AM fungus. Each value is the mean of 3 replicates. Within columns, treatments with the same letter are not significantly different (LSD $\alpha=0.05$ )

\begin{tabular}{lcc}
\hline & \multicolumn{2}{c}{ Mycorrhizal colonization (\%) } \\
\cline { 2 - 3 } Treatment & $\begin{array}{c}\text { Immediately after inoculation } \\
\text { with } F \text {. oxysporum }\end{array}$ & $\begin{array}{c}14 \text { days after inoculation } \\
\text { with } F \text {. oxysporum }\end{array}$ \\
\hline Uninoculated control & $0 \mathrm{~b}$ & $0 \mathrm{c}$ \\
$\begin{array}{l}\text { G. } \text { etunicatum } \\
\text { F. } \text { oxysporum }\end{array}$ & $36 \mathrm{a}$ & $37 \mathrm{a}$ \\
G. etunicatum $+F$. & $0 \mathrm{~b}$ & $0 \mathrm{c}$ \\
oxysporum & $36 \mathrm{a}$ & $32 \mathrm{~b}$ \\
\hline
\end{tabular}


Table 2

Fusarium wilt disease incidence and severity index of cucumber inoculated with a zoospore suspension of Fusarium oxysporum. The results were determined 14 days after inoculation with Fusarium

\begin{tabular}{lcc}
\hline Treatment & Incidence(\%) & Disease index $(\%)$ \\
\hline Uninoculated control & 0.0 & 0.0 \\
G. etunicatum & 0.0 & 0.0 \\
F. oxysporum & 12.5 & 4.1 \\
G. etunicatum + F. oxysporum & 0.0 & 0.0 \\
\hline
\end{tabular}

inoculated with $F$. oxysporum. Inoculation with $F$. oxysporum led to a decrease in the proportion of root length colonized by G. etunicatum in mycorrhizal plants, but mycorrhizal colonization remained at about $30 \%$ of root length with a decrease of about $5 \%$.

\section{Disease Development}

The incidence and disease severity index of mycorrhization with BEG168 were both decreased compared with non-mycorrhizal plants by inoculation with a zoospore suspension of $F$. oxysporum, and there was no disease incidence in the plants not inoculated with F. oxysporum (Table 2). Compared with the untreated control plants, only those inoculated with $F$. oxysporum showed typical Fusarium wilt and yellowing of the leaves with root and stem rot symptoms. In contrast, plants inoculated with G. etunicatum at germination and then inoculated $F$. oxysporum 28 days later showed no disease symptoms.

\section{Growth Parameters}

Leaf area showed no significant difference between mycorrhizal and nonmycorrhizal plants before inoculation with $F$. oxysporum but a clear effect was apparent 14 days after $F$. oxysporum inoculation (Table 3 ). Compared with the control, the plants incoculated with $F$. oxysporum had a smaller leaf area, while there was no significant difference between the controls and the plants inoculated with both the AM fungus and the Fusarium treatment 14 days after F. oxysporum inoculation.

Inoculation with $G$. etunicatum increased plant biomass significantly during the period before $F$. oxysporum inoculation (Table 3 ). Fourteen days after $F$. oxysporum inoculation there were no differences between other treatments and the control, but AM fungal inoculation produced greater plant dry weight was more than $\operatorname{did} F$. oxysporum inoculation. 
Table 3

Leaf area and dry weight of the cucumber plants. Each value is the mean of three replicates. Within each column, treatments with the same letter are not significantly different (LSD $\alpha=0.05$ )

\begin{tabular}{|c|c|c|c|c|}
\hline \multirow[b]{2}{*}{ Treatment } & \multicolumn{2}{|c|}{ Leaf area $\left(\mathrm{cm}^{2}\right)$} & \multicolumn{2}{|c|}{ Dry weight (g) } \\
\hline & $\begin{array}{c}\text { Immediately after } \\
\text { inoculation } \\
\text { with } F \text {. } \\
\text { oxysporum }\end{array}$ & $\begin{array}{l}14 \text { days after } \\
\text { inoculation } \\
\text { with } F \text {. } \\
\text { oxysporum }\end{array}$ & $\begin{array}{l}\text { Immediately after } \\
\text { inoculation } \\
\text { with } F \text {. } \\
\text { oxysporum }\end{array}$ & $\begin{array}{l}14 \text { days after } \\
\text { inoculation } \\
\text { with } F \text {. } \\
\text { oxysporum }\end{array}$ \\
\hline \multicolumn{5}{|l|}{ Uninoculated } \\
\hline control & $360 \mathrm{a}$ & $583 \mathrm{~b}$ & $1.11 \mathrm{a}$ & $3.71 \mathrm{ab}$ \\
\hline G. etunicatum & $366 a$ & $764 a$ & $1.22 \mathrm{~b}$ & $4.44 \mathrm{a}$ \\
\hline F. oxysporum & $360 \mathrm{a}$ & $481 \mathrm{c}$ & $1.11 \mathrm{a}$ & $3.11 \mathrm{~b}$ \\
\hline $\begin{array}{l}\text { G. etunicatum }+ \\
\text { F. oxysporum }\end{array}$ & $366 a$ & $564 \mathrm{~b}$ & $1.22 \mathrm{~b}$ & $3.92 \mathrm{ab}$ \\
\hline
\end{tabular}

\section{Phosphate (P) Concentration}

Shoot P concentration was increased by application of $G$. etunicatum both before inoculation with Fusarium and 14 days afterwards irrespective of whether F. oxysporum inoculation was done (Table 4). Inoculation with F. oxysporum had no influence on shoot $\mathrm{P}$ concentration.

\section{Malondialdehyde (MDA) Production}

Malondialdehyde (MDA) production of controls and plants inoculated with the AM fungus only showed no significant difference at whether before or 14 days

Table 4

Phosphorus (P) concentrations in cucumber plants. Each value is the mean of three replicates. Within each column, treatments with the same letter are not significantly different (LSD $\alpha=0.05$ )

\begin{tabular}{lcc}
\hline & \multicolumn{2}{c}{$\mathrm{P}(\mathrm{g} / \mathrm{kg})$} \\
\cline { 2 - 3 } Treatment & $\begin{array}{c}\text { Immediately after inoculation } 14 \text { days after inoculation } \\
\text { with F. oxysporum }\end{array}$ & with F. oxysporum \\
\hline Uninoculated control & $1.5 \mathrm{~b}$ & $1.4 \mathrm{~b}$ \\
G. etunicatum & $2.5 \mathrm{a}$ & $2.5 \mathrm{a}$ \\
F. oxysporum & $1.5 \mathrm{~b}$ & $1.7 \mathrm{~b}$ \\
G. etunicatum + F. oxysporum & $2.5 \mathrm{a}$ & $2.7 \mathrm{a}$ \\
\hline
\end{tabular}




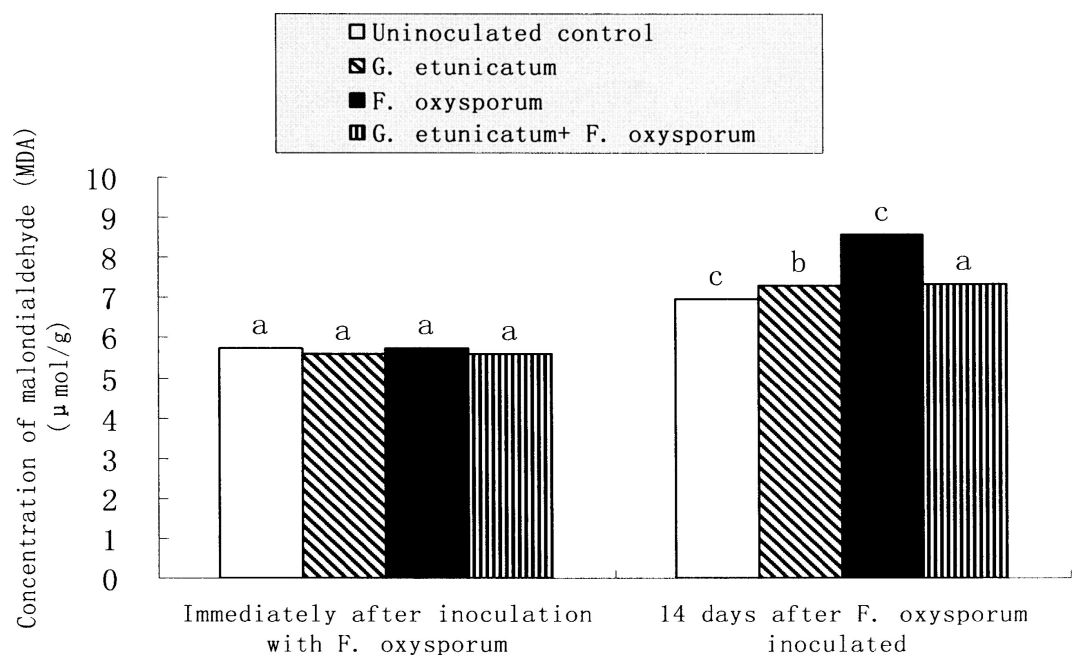

Figure 1. Malondialdehyde (MDA) concentrations in cucumber plants. Each value is the mean of three replicate. At each time, treatments with the same letter are not significantly different (LSD $\alpha=0.05)$.

after F. oxysporum inoculation (Figure 1). Fusarium oxysporum increased MDA production markedly. In contrast, there was no significant difference between the controls and the plants inoculated with both the AM and wilt fungi 14 days after $F$. oxysporum inoculation, indicating that inoculation with the AM fungus reduced the MDA concentrations under conditions of disease stress.

\section{Proline Content}

Proline concentrations were not influenced by the AM fungus during the period before $F$. oxysporum inoculation, but 14 days after $F$. oxysporum inoculation the mycorrhizal plants had higher proline concentrations than non-mycorrhizal plants (Figure 2). Inoculation with $F$. oxysporum only increased proline concentrations compared with the control, but less than inoculation with both fungi, the treatment which gave the highest proline concentrations.

\section{Polyphenol Oxidase (PPO) Activity}

Before $F$. oxysporum inoculation, there were no significant effects on PPO activity (Figure 3 ). Fourteen days after F. oxysporum inoculation the PPO activity of mycorrhizal plants was higher than of non-mycorrhizal plants. However, there was no difference between plants inoculated with $F$. oxysporum only and controls, and plants inoculated with both fungi showed the highest PPO activity. 


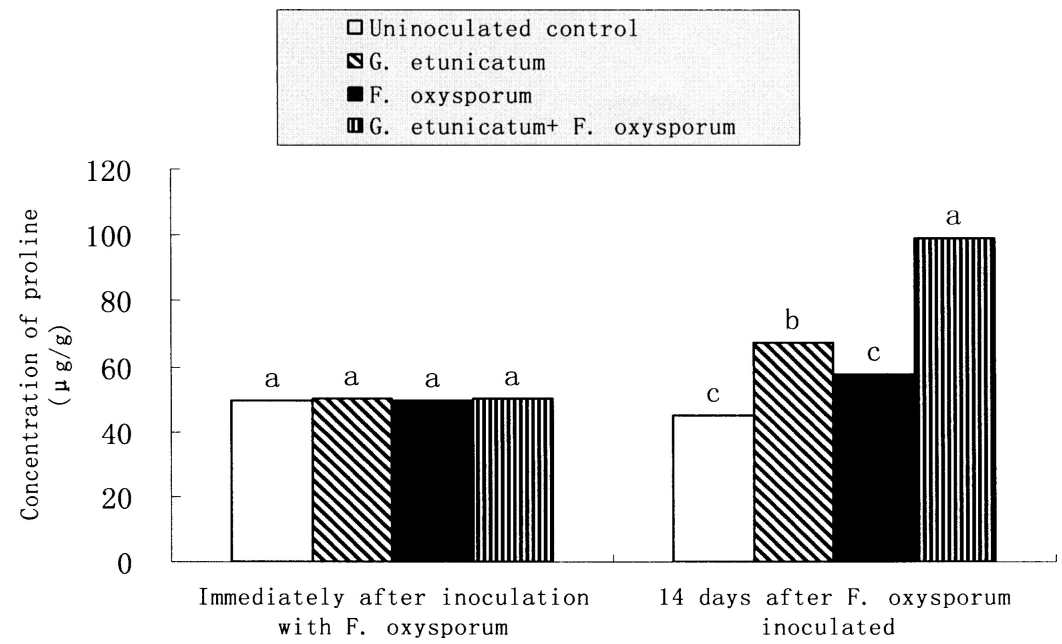

Figure 2. Proline concentrations in cucumber plants. Each value is the mean of three replicates. At each time, treatments with the same letter are not significantly different $(\operatorname{LSD} \alpha=0.05)$.

\section{DISCUSSION}

Although cucumber wilt disease does not reach its peak until the plants are producing fruit, the present study showed that the nonmycorrhizal plantlets inoculated $F$. oxysporum showed symptoms of severe root rot with dark, softened

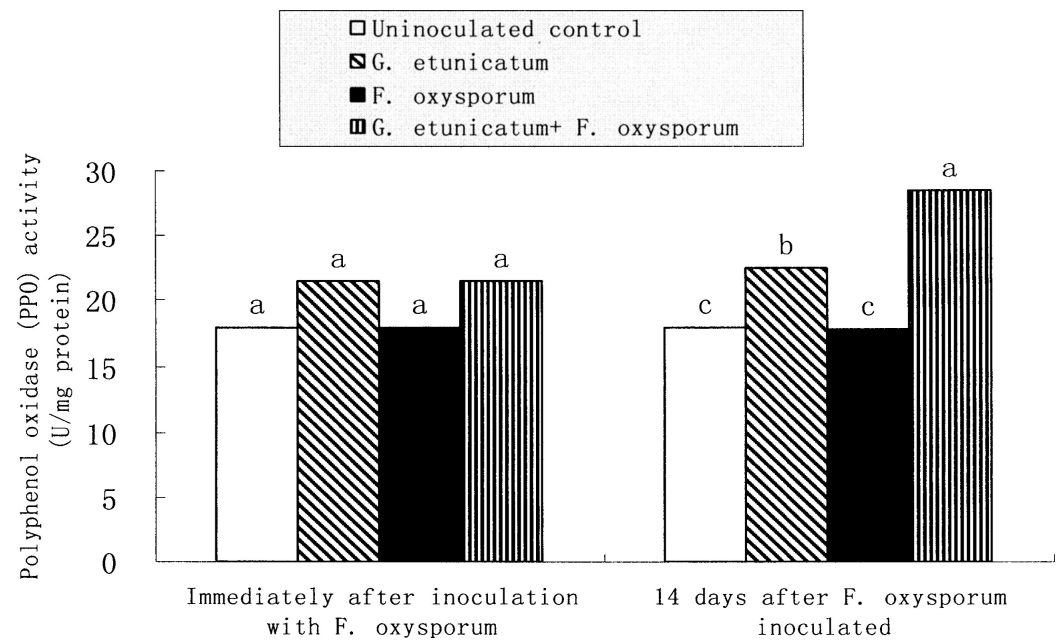

Figure 3. Polyphenol oxidase (PPO) activity in cucumber plants. Each value is the mean of three replicates. At each time, treatments with the same letter are not significantly different (LSD $\alpha=0.05$ ). 
roots and wilting of the shoots. This was in contrast to the mycorrhizal plants, which were not damaged to the same degree. The experiment confirms that the AM fungus can reduce the damage to the plants caused by the root pathogen.

Mycorrhizal colonization increased the leaf area and biomass 14 days after inoculation with $F$. oxysporum, indicating that the growth-promoting effect of the mycorrhiza required time to develop. The effect of mycorrhiza on growth may thus be related to P nutrition. Smith and Gianinazzi-Pearson (1988) pointed out that inoculation with AM fungi enhanced plant growth mainly due to $\mathrm{P}$ absorption, which might account for the higher tolerance of mycorrhizal plants to pathogens (Hooker et al., 1994; Linderman, 1994). Plant growth promotion due to AM colonization of the root systems was shown by Cordier et al. (1996) to be responsible for increased disease resistance. In contrast, inoculation with F. oxysporum decreased plant growth as a result of the damage to the plantlets from metabolic changes and water stress. The mycorrhizal plants infected with F. oxysporum were not significantly different from the controls, indicating that promotion of plant growth can ameliorate wilt disease. This is in agreement with Cordier et al. (1996) and may represent an indirect contribution to biological control of the root rot.

AM fungal colonization of plant roots induces changes in secondary metabolites that are known to alter root physiology (Linderman, 1994) and induce local and systemic resistance to fungal pathogens (Cooper and Grandison, 1986). The activation of specific plant defense mechanisms as a response to AM colonization is an obvious basis for the protective capacity of AM fungi. The elicitation by an AM symbiosis of specific plant defense reactions could predispose the plant to an early response to attack by a root pathogen (GianinazziPearson et al., 1994).

Induced premature senescence is often quantified by increases in membrane permeability and lipid peroxidation. Lipid peroxidation is usually determined by MDA content. As a rule, the cellular level of MDA is relatively low, representing a balance between the rate of univalent oxidation and the combined rates of reduction and formation of MDA. When cells suffer from oxidative stress, production of MDA is inevitable because oxidation radicals are commonly trapped, thereby generating MDA (Heber et al., 1996). There were no significant differences in MDA production between unstressed and $F$. oxysporum-inoculated mycorrhizal plants during our experiment in contrast to plants inoculated with $F$. oxysporum only and the controls. This data supports the hypothesis that the inoculation with AM fungi can reduce the production of MDA compared with non-mycorrhizal plants under $F$. oxysporum stress.

As expected, inoculation with $F$. oxysporum impeded water transport in the plants. Higher plants accumulate some metabolites in response to osmotic stress such as water stress (Delauney and Verma, 1993; Hasegawa et al., 2000). Proline appears to be the most widely distributed compatible solute in organisms ranging from bacteria to plants (Flowers et al., 1977). Some investigators have reported a positive correlation between proline accumulation and adaptation 
to water stress (Voetberg and Sharp, 1991; Kishor et al., 1995). The results of this study indicate that more exogenous proline was produced to protect mycorrhizal plants under pathogen stress. Thus, the tolerance conferred by mycorrhizal colonization may have been further promoted by increasing the proline concentration in the plants.

Because of their conspicuous reaction products and their wound and pathogen inducibilities, PPOs have frequently been suggested to participate in plant defense against pests and pathogens (Thipyapong et al., 1995, 1997). There are reports pointing out that PPO is prominent amongst the defense proteins induced in crop plants (Constabel et al., 1995; Constabel and Ryan, 1998). Inoculation with AM fungi may induce an increase in PPO activity and accumulation of defense proteins in view of reports that active quinones produced by PPOs may possess direct antibiotic and cytotoxic activities to pathogens (Peter, 1989). In the present study, the mycorrhizal plants under disease stress showed higher PPO activity than non-mycorrhizal plants, suggesting an important role of AM fungi in limiting plant disease development, and providing some evidence for the involvement of PPO in disease resistance.

The data indicate that inoculation with the AM fungus may release water stress, protect membrane permeability, promote oxidation of hydroxybenzene (which can restrain the activity of Fusarium), and reduce the extent of the damage to cucumber seedlings caused by $F$. oxysporum. Thus, the mycorrhizal fungus may improve the growth and the resistance to wilt disease of the cucumber seedlings.

Furthermore, F. oxysporum and its metabolites may suppress the growth of AM fungi and inhibit the development of the mycorrhizal association symbiosis, effects similar to those reported by Liu (1995). This may be very important since such effects may hinder the beneficial effects of AM fungi because of inhibition sporangium production, zoospore germination (Catska, 1994), and competition for host photosynthates and colonization sites (Linderman, 1994; Jalali and Jalali, 1991).

This preliminary study has indicated that inoculation with an AM fungus reduced the development of $F$. oxysporum disease on cucumber plantlets. Though the results showed beneficial effect of the AM fungus on the growth and disease resistance of the plantlets under glasshouse conditions, further studies are required to clarify whether these effects can persist over the long term and under field conditions.

\section{ACKNOWLEDGMENTS}

This work was funded by the National Science Foundation of China (Project 30230250) and the National High Technology Research and Development Program ('863' Program) of the Science Technology Department of the People's Republic of China (Project 2001AA247031). 


\section{REFERENCES}

Abbott, L. K., and A. D. Robson. 1984. The effect of mycorrhizas on plant growth. In VA mycorrhizae, eds. C. L. Powell and D. J. Bagyaraj, 113130. Boca Raton, Florida: CRC Press.

Bates, L., R. P. Waldren, and I. D. Teare. 1973. Rapid determination of free proline for water stress studies. Plant and Soil 39: 205-207.

Bonfante-Fasolo, P. 1987. Vesicular-arbuscular mycorrhizae: Fungus-plant interactions at the cellular level. Symbiosis 3: 249-268.

Brundrett, M. C., N. Bougher, B. Dell, T. Grove, and N. Malajczuk. 1996. Working with mycorrhizas in forestry and agriculture. ACIAR Monograph 32: 373.

Catska, V. 1995. Interrelationships between vesicular-arbuscular mycorrhiza and rhizosphere microflora in apple replant disease. Biologia Plantarum 36: 99-104.

Constabel, C. P., D. R. Bergey, and C. A. Ryan. 1995. Systemin activates synthesis of wound-inducible tomato leaf polyphenol oxidase via the octadecanoid defense signaling pathway. Proceedings of National Academy of Science 92: 407-411.

Constabel, C. P., and C. A. Ryan. 1998. A survey of wound- and methyl jasmonate-induced leaf polyphenol oxidase in crop plants. Phytochemistry 47: 507-511.

Cooper, K. M., and G. S. Grandison. 1986. Interaction of vesicular-arbuscular mycorrhizal fungi and root knot nematode on cultivars of tomato and white clover susceptible to Meloidogyne hapla. Annals of Applied Biology 108: $555-565$.

Cordier, C., S. Gianinazzi, and V. Gianinazzi-Pearson. 1996. Colonisation patterns of root tissues by Phytophthora nicotianae var. parasitica related to reduced disease in mycorrhizal tomato. Plant and Soil 185: 223-232.

de Boer, M., P. Born, F. Kindt, J. J. B. Keurentjes, I. van der Sluis, L. C. van Loon, and P. A. H. M. Bakker. 2003. Control of Fusarium wilt of radish by combining Pseudomonas putida strains that have different disease-suppressive mechanisms. Phytopathology 93: 626-632.

de Vos, C. H. R., H. Schat, R. Vooijs, and W. H. O. Ernst. 1989. Copper induced damage to the permeability barrier in roots of Silene cucubalus. Journal of Plant Physiology 135: 164-179.

Delauney, A. J., and D. P. S. Verma. 1993. Proline biosynthesis and osmoregulation in plants. Plant Journal 4: 215-223.

Druge U., and F. Schonbeck. 1992. Effect of arbuscular mycorrhizal infection on transpiration, photosynthesis and growth on flax (Linum usitatissimum L.) in relation to cytokinin levels. Journal of Plant Physiology 141: 40-48.

Flowers, T. J., P. F. Troke, and A. R. Yeo. 1977. The mechanism of salt tolerance in halophytes. Annual Review of Plant Physiology 28: 89121. 
Gianinazzi-Pearson, V., A. Gollotte, E. Dumas-Gaudot, P. Franken, and S. Gianinazzi. 1994. Gene expression and molecular modifications associated with plant responses to infection by arbuscular mycorrhizal fungi. In Advances in molecular genetics of plant-microbe interactions, eds. M. Daniels, J. A. Downic, and A. E. Osbourn, 179-186. Dordrecht, Netherlands: Kluwer.

Hasegawa, P. M., R. A. Bressan, J. K. Zhu, and H. J. Bohnert. 2000. Plant cellular and molecular responses to high salinity. Annual Review of Plant Physiology and Plant Molecular Biology 51: 463-499.

Heber, U., C. Miyake, J. Mano, C. Ohno, and K. Aada. 1996. Monodehydroascorbate radical detected by electron paramagnetic resonance spectrometry is a sensitive probe of oxidative stress in intact leaves. Plant Cell Physiology 37: 1066-1072.

Hooker, J. E., M. Jaizme-Vega, and D. Atkinson. 1994. Biocontrol of plant pathogens using arbuscular mycorrhizal fungi. In Impact of arbuscular mycorrhizas on sustainable agriculture and natural ecosystems, eds. S. Gianinazzi and H. Schüepp, 191-200. Basel: Birkhäuser.

Huang, Z. S., Y. R. Yang, and X. D. Zhu. 1994. Identification of pathogenic races and integrated control of Fusarium wilt of cucumber in China. Acta Agriculturae Boreali Sinica 9: 81-86.

Jalali, B. L., and I. Jalali. 1991. Mycorrhiza in plant disease control. In Handbook of applied mycology, eds. K. Arora, B. Rai, K. G. Mukerji, and G. R. Knudsen, 131-154. New York: Marcel Dekker, Inc.

Kishor, P. B. K., Z. L. Hong, G. H. Miao, C. A. A. Hu, and D P. S. Verma. 1995. Over expression of D1-pyrroline-5-carboxylate synthetase increases proline production and confers osmotolerance in transgenic plants. Plant Physiology 108: 1387-1394.

Kwon, T. W., D. B. Menzel, and H. S. Olcott. 1965. Reactivity of malondialdehyde with food constituents. Journal of Food Science 30: 808813.

Liu, R. J. 1995. Effect of vesicular-arbuscular mycorrhizal fungi on Verticillium wilt of cotton. Mycorrhiza 5: 293-297.

Lingua, G., G. D’Agostino, N. Massa, M. Antosiano, and G. Berta. 2002. Mycorrhiza-induced differential response to a yellows disease in tomato. Mycorrhiza 12: 191-198.

Linderman, R. G. 1994. Role of VAM fungi in biocontrol. In Mycorrhizae and plant health, eds. F. L. Pfleger and R. G. Linderman, 1-26. St. Paul, Minnesota: American Phytopathology Society.

Lobo, M. G., and M. P. Cano. 1998. Preservation of hermaphrodite and female papaya fruits (Carica papaya L., cv Sunrise, Solo group) by freezing: physical, physico-chemical and sensorial aspects. European Food Research and Technology 206: 343-349.

Magnoli, C. E., M. A. Saenz, S. M. Chiacchiera, and A. M. Dalcero. 1999. Natural occurrence of Fusarium species and fumonisin production by toxigenic 
strains isolated from poultry feeds in Argentina. Mycopathologia 145: 3541.

Park, C. S., T. C. Paulitz, and R. Baker. 1988. Biocontrol of Fusarium wilt of cucumber resulting from interactions between Pseudomonas putida and nonpathogenic isolates of Fusarium oxysporum. Phytopathology 78(2): 190-194.

Peter, M. G. 1989. Chemical modifications of biopolymers by quinines and quinone methides. Angewandte Chemie, International Edition in English 28: 555-570.

Rose, S., M. Parker, and Z. K. Punja. 2003. Efficacy of biological and chemical treatments for control of Fusarium root and stem rot on greenhouse cucumber. Plant Disease 87: 1462-1470.

Shaul, O., S. Galili, H. Volpin, I. Ginzberg, Y. Elad, I. Chet, and Y. Kapulnik. 1999. Mycorrhiza-induced changes in disease severity and PR protein expression in tobacco leaves. Molecular Plant-Microbe Interactions 12: 1000-1007.

Smith, S. E., and V. Gianinazzi-Pearson. 1988. Physiological interactions between symbionts in vesicular-arbuscular mycorrhizal plants. Annual Review of Plant Physiology and Plant Molecular Biology 39: 221-244.

Thipyapong, P., M. D. Hunt, and J. C. Steffens. 1995. Systemic wound induction of potato (Solanum tuberosum) polyphenol oxidase. Phytochemistry 40: 673-676.

Thipyapong, P., D. M. Joel, and J. C. Steffens. 1997. Differential expression and turnover of the tomato polyphenol oxidase gene family during vegetative and reproductive development. Plant Physiology 113: 707-718.

Trotta, A., G. C. Varese, E. Gnavi, A. Fusconi, S. Sampò, and G. Berta. 1996. Interactions between the soil-borne root pathogen Phytophthora nicotianae var parasitica and the arbuscular mycorrhizal fungus Glomus mosseae in tomato plants. Plant and Soil 185: 199-209.

Vakalounakis, D. J., Z. Wang, G. Fragkiadakis, G. N. Skaracis, and D. B. Li. 2004. Characterization of Fusarium oxysporum isolates obtained from cucumber in China by pathogenicity, VCG, and RAPD. Plant Disease 88: 645-649.

Voetberg, G. S., and R. E. Sharp. 1991. Growth of the maize primary root at low water potentials. 3. Role of increased proline deposition in osmotic adjustment. Plant Physiology 96: 1125-1130. 